\title{
К ВОПРОСУ О ПОНЯТИИ И СУЩНОСТИ ВОДОСНАБЖЕНИЯ И ВОДООТВЕДЕНИЯ В РОССИЙСКОЙ ФЕДЕРАЦИИ
}

\section{ON THE QUESTION OF THE CONCEPT AND ESSENCE OF WATER SUPPLY AND SANITATION IN THE RUSSIAN FEDERATION}

\section{Kuznetsova \\ T. Matveeva \\ N. Kuznetsova}

Summary. The article discusses the issues of water supply and sanitation in the Russian Federation. The authors analyze both regulatory legal acts regulating the processes of water resources use and the opinions of scientists considering these two concepts. The relevance of the topic under consideration shows the need to highlight issues related to the use of water resources and their impact on the environment. The sanitary and epidemiological well-being of the population, its health, standard of living, improvement of cities and towns largely depends on the quality and safety of water that is supplied and distributed through centralized and non-centralized water supply systems. The solution of the problems associated with sanitation and water supply identified by the authors is of paramount importance.

Keywords: water resources, water supply, sanitation, ecosystem, natural water resources, vital activity of villages.
Кузнецова Инна Анатольевна

К.ю.н., доцент, Владимирский филиал РАНХИГС,

2. Владимир

kyzina33@mail.ru

Матвеева Тамара Павловна

Старший преподаватель, ФКОУ ВО «Владимирский юридический институт ФСИН России» matveeva33@mail.ru Кузнецова Наталья Александровна

Старший преподаватель, ФКОУ ВО «Владимирский юридический институт ФСИН России»

kuz1503@yandex.ru

Аннотация. В статье рассматриваются вопросы водоснабжения и водоотведения в Российской Федерации. Авторами анализируются как нормативные правовые акты, регулирующие процессы использования водных ресурсов, так и мнения ученых рассматривающих эти два понятия. Актуальность рассматриваемой темы показывает необходимость освещения вопросов касающихся использования водных ресурсов и их влияние на окружающую среду. От качества и безопасности воды, которая подается и распределяется через централизованные и нецентрализованные системы водоснабжения во многом зависит санитарно-эпидемиологическое благополучие населения его здоровье, уровень жизни, благоустройство городов и поселков. Решение проблем, связанных с водоотведением и водоснабжением, выделенных авторами имеет первостепенное значение.

Ключевые слова: водные ресурсы, водоснабжение, водоотведение, экосистема, природные ресурсы воды, жизнедеятельность населения.
B одные ресурсы, будучи одним из основных биологических элементов, необходимых для поддержания жизнедеятельности человека, с давних времен традиционно принято относить к неисчерпаемым природным ресурсам [13] в силу того, что за счет круговорота воды в природной системе она подлежит самовосстановлению и самоочищению. С указанным мнением можно согласиться лишь отчасти: безусловно, в процессе жизнедеятельности экосистемы вода постоянно циркулирует в природе, изменяя свое состояние. Так, согласно исследованиям, в связи с ежегодным испарением воды из мирового океана образуется около 525 тыс. кубических километров пресной воды. Данная вода впоследствии попадает, в том числе, и в пресноводные водоемы, пополняя их водные запасы.[10] Однако, на наш взгляд, воду следует относить к категории исчерпаемых природных ресурсов в силу того, что по мере ее использования коэффициент по- лезного потребления воды постепенно сокращается, что выражается в уменьшении возможностей повторного использования воды на определенные нужды. Этому необратимому процессу способствует сразу несколько факторов: изменение климатических условий (повышение температуры по всей планете, что приводит к засухам в одних регионах, таянию ледников и снежных покровов в других); увеличение потребления воды на нужды сельского хозяйства, производства, промышленности и, как следствие, повышение уровня выбросов и отходов в окружающую среду, в том числе сточных вод и загрязняющих и ядовитых веществ в водоемы, грунтовые воды; увеличение населения, урбанизация и иные причины. Данные проблемы обуславливают ухудшение уровня жизни населения, в связи с чем можно констатировать, что основной задачей человечества на сегодняшний день должно выступать повышение эффективности рационального использо- 
вания водных ресурсов, что может быть обеспечено, в частности, за счет грамотно выстроенной и отлаженной системы водоснабжения и водоотведения.

Деятельность по водоснабжению и водоотведению в Российской Федерации направлена на обеспечение потребностей в воде таких субъектов, как население городов и пригородных поселений, государственные учреждения (образовательные, медицинские, правоохранительные и т.д.), различные промышленные и непромышленные предприятия и т.д. Реализуется такая деятельность специальными субъектами - организациями водопроводно-канализационного хозяйства, которые в рамках указанной деятельности осуществляют эксплуатацию систем холодного водоснабжения/водоотведения, а также теплоснабжающими организациями (по отношению к горячему водоснабжению).

Одним из основных отраслевых нормативно-правовых актов, регулирующих общественные отношения, вытекающие из водоснабжения и водоотведения, выступает Федеральный закон «О водоснабжении и водоотведении» от 07.12.2011 № 416-Ф3.[1] В частности, в ст. 2 указанного закона представлены дефиниции водоснабжения и водоотведения. Так, под водоснабжением понимается «водоподготовка, транспортировка и подача питьевой или технической воды абонентам с использованием централизованных или нецентрализованный систем холодного водоснабжения (холодное водоснабжение) или приготовление, транспортировка и подача горячей воды абонентам с использованием централизованных или нецентрализованных систем горячего водоснабжения (горячее водоснабжение)». В свою очередь, водоотведение исходя из положений Федерального закона № 416-Ф3 представляет собой «прием, транспортировку и очистку сточных вод с использованием централизованной системы водоотведения».

Законодательное определение водоснабжения закреплено также в Постановлении Правительства Российской Федерации от 06.05.2011 № 354 «О предоставлении коммунальных услуг собственникам и пользователям помещений в многоквартирных домах и жилых домов». В нормативном правовом акте водоснабжение разделяется на холодное и горячее и сводится к снабжению водой жилых и нежилых помещений многоквартирных домов, а также входящих в состав общего имущества многоквартирного дома помещений. Под холодным водоснабжением, согласно указанному постановлению, понимается процесс снабжения холодной питьевой водой, осуществляемого через централизованные сети холодного водоснабжения и инженерным системам; под горячим водоснабжением понимается процесс снабжения горячей водой, подаваемой через централизованные сети горячего водоснабжения, а также по инженерным системам [2]. Данные определения представляются чрезмерно узкими, поскольку не включают в понятие водоснабжения подачу воды в иные, не указанные в Постановлении Правительства Российской Федерации № 354 помещения. В связи с этим, наиболее целесообразным было бы обозначение указанных дефиниций как горячее и холодное водоснабжение, предоставляемое в виде услуги собственникам и пользователям помещений в многоквартирных и жилых домах.

Несмотря на наличие законодательно закрепленных определений понятий «водоснабжение» и «водоотведение», в научной сфере существует множество иных трактовок. Если обратиться к специальной, технической литературе, можно встретить и другие определения. Так, Н.Н. Абрамов под водоснабжением понимает комплекс мероприятий по обеспечению водой потребителей.[3] Данного определения может быть достаточно для целей технических наук. Однако для юриспруденции его вряд ли можно назвать идеальным, поскольку, в силу своей чрезмерной обобщенности оно не дает представления о существенных признаках, отличающих водоснабжение от иных явлений и процессов. Например, под данное определение вполне можно подвести процесс поставки бутилированной воды потребителям. Аналогичное определение водоснабжения можно встретить и в толковых словарях: так, в толковом словаре под редакцией С.А. Кузнецова под данным термином понимается снабжение населения и промышленных объектов водой.[9]

Иная точка зрения сводится к тому, что водоснабжение - это система инженерных сооружений, направленных на обеспечение пользователей доброкачественной водой.[7] Авторы данного подхода подчеркивают такой признак поставляемой воды, как доброкачественность, что, на наш взгляд, является существенным дополнением. Так, в определении водоснабжения, закрепленном в Федеральном законе № 416-Ф3 «О водоснабжении и водоотведении», не содержится указанной характеристики качества, что представляется упущением, поскольку в таком случае утрачивается значимость одной из основных задач водоснабжения - улучшение качества жизни общества (при снабжении некачественной водой возможны отравление человека, животного, плантаций, неправильная работа оборудования и т.д.).

Исследуя понятие водоснабжения, П.Л.Аронова определяет его через задачи, поставленные перед сооружениями и устройствами, осуществляющими водоснабжение: непосредственно извлечение воды из водных источников, ее последующая транспортировка 
до соответствующих точек, а также поставка и распределение потребителям.[4] Такого же метода при определении водоснабжения придерживаются Б.Ф. Лямаев, В.И. Кириленко и В.А.Нелюбов, по мнению которых водоснабжение включает в себя прием воды, ее транспортировку, доведение до необходимых кондиций, подачу и распределение по точкам, а также бесперебойный набор необходимого количества воды с заданным напором и режимом.[11]

И.В. Беренштейн, посвятившая свое исследование правовому регулированию водоснабжения и водоотведения в Российской Федерации, определяет водоснабжение как совокупность мероприятий, направленных на обеспечение водой потребителей.[5]

Что касается понятия «водоотведение» в специальной литературе, а также толковых словарях его определение в своем большинстве также предложено в весьма обобщенном формате. Например, в толковом словаре С.И. Ожегова и Н.Ю. Шведовой содержится слово «водоотводный», под которым понимается водоотводное сооружение, либо сооружение, предназначенное для отвода воды в сторону.[12] Исходя, из этого определения можно сказать, что под водоотведением понимается непосредственно сам процесс отведения воды. По мнению специалистов в сфере строительства М.Л.Дромылец и В.Д.Жигалко, под водоотведением следует понимать «совокупность технических построек и санитарных мероприятий, которые обеспечивают прием сточных вод от населения и промышленных предприятий, а также осуществляют перемещение и очистку их с последующим сбросом в реку или на рельеф».[8] Соответственно, в отличие от определений, содержащихся в толковых словарях, указанные авторы рассматривают понятие водоотведения не как процесс, а как систему сооружений, построек и мероприятий, основной задачей которых как раз и выступает обеспечение процесса отвода воды.

Весьма полное определение водоотведения представлено группой авторов учебника по железнодорожному водоснабжению и водоотведению - В.С. Дикаревским, П.П. Якубчик, В.Г. Ивановым и Е.Г.Петровым. По их мнению, водоотведение - это система сооружений и мероприятий, обеспечивающих сбор сточных вод, их последующий отвод за пределы жилых территорий, промышленных предприятий и иных мест для очистки и обезвреживания в целях дальнейшего использования в техническом водоснабжении, или, при необходимости, в целях сброса в водные объекты при сохранении нормальной деятельности последних. [7]

Определение водоотведения содержится и в упоминаемом выше Постановлении Правительства Российской Федерации от 06.05.2011 № 354. Согласно п. 4 которого, под данным термином понимается отведение сточных вод из жилого или многоквартирного дома по централизованным сетям водоотведения и инженерным системам.[2] К данному определению имеется аналогичное замечание, которое возникло по отношению к трактовкам горячего и холодного водоснабжения. По указанному постановлению определение водоотведения не охватывает процесс отвода воды из иных помещений, помимо жилых, не включенных данным пунктом в содержание анализируемого понятия. Соответственно, в данном случае речь идет не о водоотведении в его общем значении, а о водоотведении из жилых и многоквартирных домов.

Д.М. Будницкий, анализируя определение, предложенное законодателем в рамках Федерального закона № 416-Ф3, считает целесообразным его дополнить, включив в дефиницию водоснабжения также процесс по забору/изъятию водных ресурсов из водного объекта, а в дефиницию водоотведения - процесс сброса сточных вод в водные объекты. [6]

На наш взгляд, в данном суждении есть лишь доля правды: так, безукоризненно можно согласиться с Д.М. Будницким относительно определения водоотвода, поскольку включение процесса сброса сточных вод в процесс водоотведения оправдывается юридическим содержанием правового статуса организаций, осуществляющих водоотведение, среди основных обязанностей которых по договору водоотведения, выделяется такая, как обеспечение сброса сточных вод абонента в водный объект (п. 1 ст. 14 Федерального закон РФ № 416-Ф3).

В свою очередь, внесение дополнений в определение водоснабжения, по мнению автора, обусловлены тем, что при водоснабжении определяющее воздействие на окружающую среду оказывается именно в процессе забора воды. Однако гораздо большее воздействие на окружающую среду оказывается при водоотведении, в рамках которого сточные воды и отходы сбрасываются в водные объекты. Соответственно, согласно логике автора, в понятие «водоснабжение» должно быть включено также и содержание понятия «водоотведение», что само по себе не может являться верным предположением, поскольку речь идет о двух совершенно противоположных процессах. Более того, о негативном воздействии на окружающую среду можно говорить и на более ранних стадиях, предшествующих процессу водоснабжения и забору воды, вплоть до строительства водоснабжающих сооружений, подготовки планов и территорий строительства систем, однако включение данных стадий в содержание водоснабжения лишь по принципу их отрицательного воздействия на окружающую среду является абсурдным. 
Проведенное исследование понятия водоснабжения и водоотведения показало, что единого подхода к определению данных категорий не сложилось. Помимо легальных определений, содержащихся в российском законодательстве, существует множество точек зрения по данному вопросу. Было выявлено, что научные трактовки исследуемых понятий различаются по их сущности (водоснабжение и водоотведение рассматриваются как процесс или как система сооружений и мероприятий), по содержанию (например, включение в водоотведение процесса забора воды), по существенным признакам (например, доброкачественность) и т.д. Подытоживая вышесказанное представляется целесообразным сформулировать авторское определение по- нятий «водоснабжение» и «водоотведение». Водоснабжение представляет собой процесс снабжения водой, включающий в себя водоподготовку, транспортировку и подачу отвечающей санитарно-эпидемиологическим правилам холодной или горячей воды, посредством централизованных или нецентрализованных систем водоснабжения. Под водоотведением следует понимать процесс отведения воды из определенных зон (жилых, промышленных, сельскохозяйственных и т.д.), включающий в себя ее забор, транспортировку, очистку и обезвреживание в целях повторного использования воды в техническом водоснабжении, либо, при соблюдении санитарно-эпидемиологических правил, для последующего сброса в водные объекты.

\section{ЛИТЕРАТУРА}

1. Федеральный закон от 07.12.2011 № 416-Ф3 «0 водоснабжении и водоотведении» // Собрание законодательства РФ, 12.12.2011, 一 № 50, — ст. 7358.

2. Постановление Правительства РФ от 06.05.2011 № 354 «0 предоставлении коммунальных услуг собственникам и пользователям помещений в многоквартирных домах и жилых домов» // Собрание законодательства РФ, 30.05.2011, — № 22, — ст. 3168.

3. Абрамов Н.Н. Водоснабжение. Учебник для вузов. Изд. 2-е, перераб. и доп. М, Стройиздат, 1974. - С. 6.

4. Аронова П.Л. Водоснабжение: проектирование систем и сооружений. М.: Прогно3, 2015.— С. 19.

5. Беренштейн И.В. Правовое регулирование водоснабжения и водоотведения в Российской Федерации: автореферат дис. ... кандидата юридических наук: 12.00.03 / Моск. гос. ун-т им. М.В. Ломоносова. — Москва, 2006. - С. 16.

6. Будницкий Д.М. Правовое регулирование воздействия на природную среду в процессе деятельности по водоснабжению и водоотведению: дис. ... канд. юрид. наук: 12.00.06 / Будницкий Дмитрий Михайлович. СПб, 2015.- С. 17.

7. Дикаревский В.С. Водоснабжение и водоотведение на железнодорожном транспорте: Учебник для вузов железнодорожного транспорта/ В.С. Дикаревский, П.П. Якубчик, В.Г. Иванов, Е.Г. Петров. М.: Транспорт. 1999. - С. 7.

8. Дромылец М.Л., Жигалко В.Д. Расчет водопроводных сетей. М.: Стройиздат, 2012.- С. 108.

9. Кузнецов С.А. Большой толковый словарь русского языка СПб.: Норинт, 2006. — C. 204 (1536 с.)

10. Лашков Г.А. Запасы и проблемы пресной воды в мире // Всероссийская научно-техническая конференция. Москва. 2011.— С. 306.

11. Лямаев Б.Ф. Системы водоснабжения и водоотведения зданий: учебное пособие / Б.Ф. Лямаев, В.И. Кириленко, В.А. Нелюбов. 2-е изд. Санкт-Петербург: Политехника, 2020.-С. 6.

12. Ожегов С.И. Толковый словарь русского языка / С.И. Ожегов, Н.Ю. Шведова. 4-е изд., доп. Москва: Азбуковник, 2000.— С. 197.

13. Шимко Д.А., Бондарчик 0.Б. Проблема дефицита пресной воды в мире // Alfabuild. 1(1). 2017. 7-15.— С. 7. 